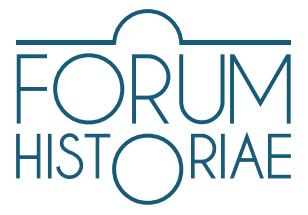

\title{
The anarcho-feminist zine "Bloody Mary" and the influence of the Internet: The problem with the hierarchy of the collective creative process
}

\author{
Mahulena Kopecká
}

\begin{abstract}
KOPECKÁ, Mahulena: The anarcho-feminist zine "Bloody Mary" and the influence of the Internet: The problem with the hierarchy of the collective creative process.

This article describes the conclusions from my postgraduate thesis, which maps the changes of the anarcho-feminist zine Bloody Mary and its transformations under the impact of the Internet, blogging and the computer graphics software used in the production of the zine. The main sources used in this case study were the issues of the zine ${ }^{1}$, interviews conducted with the authors and the readers, as well as materials published on the author's blog. I have explored several categories emerging during the analysis in addition to determining the impact of personal computers and the Internet on the changes within these categories. In this sense, one can trace the influence the Internet had in some of the sources used in the zine, in the zine's format and in its ties to anarchist and feminist groups abroad. However, other categories were not entirely influenced by the Internet to such a great extent, partly owing to the authors' approach to feminism, their description of queer topics or by their material surroundings. As such, they were impacted by the environment in which the zine was made, as well as by the lives of the authors.
\end{abstract}

Keywords: Riot Grrrls, anarchofeminism, subculture, anarchist movement, alternative media, feminism DOI: https://doi.org/10.31577/forhist.2020.14.2.8

In the era of digital communication, zines as physical artifacts connect authors and readers and create a closer communication channel than social media and e-mails. However, this was not the original shape of the zine - its form, role and purpose was transformed with the expansion of the Internet. This is the case of Czech punk feminist zine Bloody Mary published between 2000 and 2010, in an age when the computer was becoming a common communication and working tool. This article ${ }^{2}$ is based on my postgraduate thesis examining the changes of Bloody Mary in connection with the use of the Internet. The article seeks to summarize the answers to the question of how this alternative medium may have changed under the influence of a new technology and to what extent the Internet influenced the form, content and the reader's perception of the zine.

The appearance of zines has transformed with changes in technology used during their production and with the topics they have dealt with. Zines are independent media; the creator publishes them by him or herself, independently, without

1 The volumes of the Bloody Mary zines used in this research are stored in The Czech and Slovak Archive of Subcultures (For more details, see: http://ziny.info/) and the Gender Studies Library (For more details, see: https://genderstudies.cz/gender-studies/knihovna.shtml).

2 The article is based on the diploma thesis Transformations of the feminist zine Bloody Mary and how it was impacted by internet which was written as a final MA thesis at the Institute of Communication Studies and Journalism, Faculty of Social Sciences, Charles University. 
expecting a profit. If they are published periodically, they seldom stick to regularity. ${ }^{3}$ The word "zine" is derived from the term "fanzine," referring to the phrase "fan magazine". These amateur publications were originally created in communities of sci-fi literature fandoms. In the 1970s they became a part of the underground media scene and punk subculture. ${ }^{5}$ In the 1980s, the use of the term "zine" was established to refer to a broader sphere of publications that were no longer just about a fandom or a cultural object but also about everyday life and lived experience. The medium is rather an expression of self or of a community. ${ }^{6}$

The process of creating zines is free from professionalization and hierarchy; there is no division of editorial roles, and the creators can be active throughout the whole process of creating the publication. ${ }^{7}$ Zines manifest the concept of participative culture, which emphasizes diversity, mutual interactions, the ability to freely make decisions, and an opportunity to express oneself through various forms. ${ }^{8}$ The important dimension is the materiality; much of the pleasure of reading zines stems from the act of physical possession of the artifact and the act of reading. The existence of zines is reminiscent of the creator's presence. They offer emotional expression, either positive or negative, through physical interaction, ${ }^{9}$ which social media and the Internet are not able to fully provide. The materiality of zines makes them rare; it supports the formation of a relationship of the creator and the recipient. ${ }^{10}$ Zines intentionally show scratches, errors, crooked clippings, and other gestures serving as evidence of the creative process and the presence of the creator. ${ }^{11}$

Although zines may be perceived as alternative media opposed to the state and the market, Waltz notes that only some of these alternative media are created and disseminated in ways that are radically different from mainstream business practices. ${ }^{12}$ As Michael Albert from the activist publication $Z$ Magazine said, alternative media are not only characterized by their content or a nonmainstream audience, but being alternative must be related to the organization of the medium. ${ }^{13}$ Chris Atton writes that it is essential not only to take into account the content of the media but also the presentation and organizational

3 DODGE, Chris. Pushing the boundaries - Zines and libraries. In Wilson Library Bulletin, 1995, Vol. 69, No. 9, pp. 1-2, https://eric.ed.gov/?id=EJ503434.

4 RADWAY, Janice. Zines, Half-Lives, and Afterlives: On the Temporalities of Social and Political Change. In PMLA, 2011, Vol. 126, No. 1, p. 140, https://www.mlajournals.org/doi/abs/10.1632/ pmla.2011.126.1.140.

5 ATTON, Chris. Alternative media. Thousand Oaks, CA: SAGE, 2002, pp. 55-57.

6 ATTON 2002, pp. 54-55.

7 LOVATA, Troy. Zines: individual to community. In KNOWLES, J. Garry - COLE, Ardra L. Handbook of the Arts in Qualitative Research: Perspectives, Methodologies, Examples, and Issues. Thousand Oaks, CA : SAGE Publications, Inc., 2008, p. 2, https://methods.sagepub.com/book/handbook-of-the-arts-in-qualitative-research/n27.xml.

8 JENKINS, Henry - ITO, Mizuko - BOYD, Danah. Participatory Culture in a Networked Era: A Conversation on Youth, Learning, Commerce, and Politics. Cambridge: Polity, 2016, p. 2.

9 PIEPMEIER, Alison. Why Zines Matter: Materiality and the Creation of Embodied Community. In American Periodicals: A Journal of History, 2008, Vol. 18, No. 2, p. 230.

10 CLARK-PARSONS, Rosemary. Feminist Ephemera in a Digital World: Theorizing Zines as Networked Feminist Practice. In Communication, Culture and Critique, 2017, Vol. 10, No. 4, p. 567.

11 PIEPMEIER 2008, p. 222.

12 WALTZ, Mitzi. Alternative and Activist Media. Edinburgh : Edinburgh University Press, 2005, p. 2.

13 WALTZ 2005, p. 2-3. 
procedures. ${ }^{14}$ Using Michael Traber's notion of alternative media, Atton describes these media as forms whose aim is to "change towards a more equitable social, cultural and economic whole in which the individual is not reduced to an object (of the media or the political powers), but is able to find fulfillment as a total human being". ${ }^{15}$ These media forms try to convey subversive messages, disrupt social order and encourage changes in society. Most of these political features emerged in the zines of the feminist movement in the 1990s, but feminists recognized the importance of having their own alternative media a long time ago. ${ }^{16}$

\section{Feminist zines as a type of alternative media}

The feminist movement often used its own independent media as a means of resistance. The movement viewed the mass media as the main tool used by society to maintain the values arising from the stereotypical patriarchal hegemonic conception of femininity. The media serve as a tool of social control, spreading a stereotypical conception of femininity. ${ }^{17}$ Thus, the movement established its own media - the history of feminism can be read in connection with the history of the development of feminist independent publications. ${ }^{18}$ The suffragette movement produced its own press, postcards, and posters, ${ }^{19}$ such as British feminist newspaper Votes for Women. ${ }^{20}$ The second wave of feminism used leaflets and brochures, including the American magazine Off Our Backs or the British magazine Spare Rib. ${ }^{21}$

In the early 1990s, the underground feminist punk movement Riot Grrrls formed in Olympia, Washington; it is often associated with the emergence of third-wave feminism. Riot Grrrls responded to sexism in mass media, and their approach was based on the do-it-yourself (DIY) culture. ${ }^{22}$ The movement emphasized the political role of cultural activism, organized community, and the production of alternative space. ${ }^{23}$ Riot Grrrl zines used several strategies to fight against the stereotypical concept of femininity in the mainstream media, such as placing pop-cultural texts into new contexts and giving them new meanings. Even though zines may in some cases reproduce the norms of mainstream society (such is the

14 ATTON 2002, pp. 15-16.

15 TRABER, Michael. Alternative Journalism, Alternative Media (Communication Resource, no. 7, October), London: World Association for Christian Communication, 1985, p. 3 in ATTON 2002, p. 16.

16 ZOBL, Elke - DRÜEKE, Ricarda. Feminist Media: Participatory Spaces, Networks and Cultural Citizenship. Bielefeld : Transcript Verlag, 2014, p. 11.

17 VAN ZOONEN, Liesbet. Feminist perspectives on the media. In CURRAN, James - Michael GUREVITCH (eds.) Mass Media and Society. 4. London : Arnold, 1996, p. 40.

18 CLARK-PARSONS, Rosemary. Feminist Ephemera in a Digital World: Theorizing Zines as Networked Feminist Practice. In Communication, Culture and Critique, 2017, Vol. 10, No. 4, p. 557.

19 LUMSDEN, Linda J. Historiography: Woman Suffrage and the Media. In American Journalism, 2019 , Vol. 36, No. 1, p. 5.

20 PAYNE, Jenny Gunnarsson. Feminist Media as Alternative Media? Theorising Feminist Media from the Perspective of Alternative Media Studies. In ZOBL, Elke - DRÜEKE, Ricarda (eds.) Feminist Media: Participatory Spaces, Networks and Cultural Citizenship. Bielefeld : Transcript Verlag, 2014, p. 56.

21 PAYNE 2014, p. 56.

22 GOULDING, Cathlin. The Spaces in which We Appear to Each Other: The Pedagogy of Resistance Stories in Zines by Asian American Riot Grrrls. In Journal of Cultural Research in Art Education, 2015, Vol. 32, p. 161-162.

23 CHIDGEY, Red. Hand-Made Memories: Remediating Cultural Memory in DIY Feminist Networks. In ZOBL, Elke - DRÜEKE, Ricarda (eds.). Feminist Media: Participatory Spaces, Networks and Cultural Citizenship. Bielefeld : Transcript Verlag, 2014, p. 103. 
case of skinhead or metal zines containing racial, gender and sexual stereotypes), feminist zines aim to provide a safe space unaffected by the restrictive norms of commercial media regarding race, gender, and sexuality. Feminist authors make these norms visible by removing the dominant portrayal of women from commercial media and giving them new contexts which criticize these norms and offer an alternative. ${ }^{24}$ Pop culture is full of puns with many meanings, offering a space for parodies and subversions. ${ }^{25}$ Another strategy is highlighting inequalities in society through women's personal experiences and reflections of the private sphere - by writing about domestic violence, sexual harassment, or the perception of one's own body. ${ }^{26}$

\section{The anarcho-feminist zine Bloody Mary: Against sexism in society and subculture}

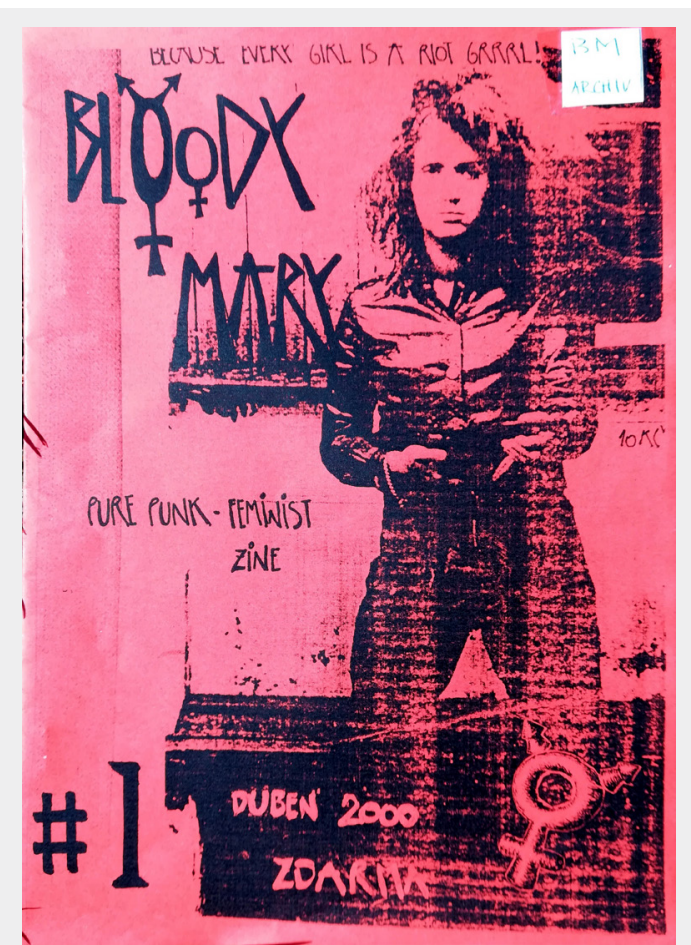

Figure 1. Source: Bloody Mary, 2000, No. 1.

The first issue of Bloody Mary was published in April 2000. The zine was highly informal, amateurish, and often extreme in terms of opinions or expressions considering the Czech perception of feminism at the time of its creation. ${ }^{27}$ The authors were closely connected to the Gender Studies Library in Prague. One of the original founders was Kamila Remišová Věšínová - she published the first issue with her friends from grammar school, but later she left the collective because she had a job outside of Prague. ${ }^{28}$ Afterwards, Jitka Kolářová joined the collective. In addition to Bloody Mary, she also published zines $Q$ Kvér and Femidom and co-organised feminist concerts and the queer Gender Fuck Fest festival. ${ }^{29}$

The creators' motivation was to inform and provide a new perspective, as the author Jitka Kolářová said: “We want to show that women also have something to say. [...] We want to spread feminist and Riot Grrrl opinions and thoughts. And we want

24 ZOBL, Elke. Cultural Production, Transnational Networking, and Critical Reflection in Feminist Zines. In Signs, 2009, Vol. 35, No. 1, pp. 2-10, https://www.jstor.org/stable/10.1086/599256.

25 FISKE, John. Reading the Popular. London - New York : Routledge, 1989, p. 6.

26 ZOBL, Elke. The Power of Pen Publishing: International grrrl zines and distros. In Feminist Collections: A Quarterly of Women's Studies Resources, 2004, Vol. 26, No. 1, p. 20.

27 CHALOUPKOVÁ, Jana. Současný anarchofeminismus v ČR. Master Thesis. Praha : Univerzita Karlova v Praze, Fakulta sociálních věd, Institut politologických studií, 2014, p. 24.

28 Interview with Kamila Remišová Věšínová, the author of Bloody Mary zine. Praha 11. 5. 2020. In KOPECKÁ, Mahulena. Proměny feministického zinu Bloody Mary s př́chodem internetu. Master Thesis. Praha : Univerzita Karlova, Fakulta sociálních věd, Institut komunikačních studií a žurnalistiky, 2020, Př́loha (Appendix) 2, https://dspace.cuni.cz/bitstream/handle/20.500.11956/121600/120371484.pdf?sequence $=1 \&$ is Allowed $=\mathrm{y}$.

29 JENKINS, Henry. The Czech Zine Scene (Part 3): Feminism. In Henry Jenkins [online], 27. 2. 2018, http:// henryjenkins.org/blog/2017/12/26/the-czech-zine-scene-part-three-feminism. 
to have fun and entertain other people as well.,30 The Bloody Mary issues were thematic and eventually reached over 50 pages. The authors combined more serious feminist articles with entertaining formats and they did not want to be too academic. Humor was an important tool, because the zine wanted to be entertaining and cover topics in a way that is understandable to as many readers as possible. ${ }^{31}$ The reflection of social inequalities in everyday life was also crucial: "We don't care about big slogans, but about seemingly banal phenomena that we either reproduce or subvert in our everyday life."32

The main motivation of the Bloody Mary collective was to reflect sexism and fill a gap in an environment that addresses various topics but does not give a space to women's activism and girls' voices. Their manifesto highlighted the female community and the need to create their own space, which should connect political issues with entertainment: "If the (public) world is masculine, we want to create our own feminine space, where our voices can be heard."33 The reflection of the position of women in the activist movement and the punk subculture was essential. Anarchists rejected criticism of sexism within the movement. Bloody Mary wrote about the experiences of sexual harassment at concerts and the anarchists' approach to feminism. ${ }^{34}$ The collective was part of other anarchist and ecological activities, and the authors were connected with the alter-globalization movement ${ }^{35}$ as well as the Feminist Group of March 8, (later renamed to the Anarchist Feminist Group). The author Kamila Remišová Věšínová said: "In the beginning we were a part of the Feminist Group; we wrote to Prímá cesta, but then we left because we didn't want to make a political magazine". ${ }^{36}$

The passion for DIY activism and cultural creation was characteristic for Bloody Mary, with the authors emphasizing DIY ethics. Their perception of DIY culture was associated with political activism directed from below and how it should connect political protest with entertainment - they used the motto "protest and have fun" ${ }^{37}$ The DIY approach was reflected in the emphasis on DIY fashion creating clothes and modifying old clothes worked at the level of everyday life "it can slowly break down the barriers of prejudice and the lack of freedom that bind $u s^{\prime \prime} .^{38}$ DIY was an act of returning power over our everyday life to our own hands. ${ }^{39}$

30 KOLÁŘOVÁ in ZOBL, Elke. The Power of Pen Publishing: International grrrl zines and distros. In Feminist Collections: A Quarterly of Women's Studies Resources, 2004, Vol. 26, No. 1, p. 23.

31 KOPECKÁ, Mahulena. Proměny feministického zinu Bloody Mary s príchodem internetu. Master Thesis. Praha : Univerzita Karlova, Fakulta sociálních věd, Institut komunikačních studií a žurnalistiky, 2020, p. 39, http://hdl.handle.net/20.500.11956/121600

32 REVOLUCE EMČA. Tak nějak o BM. In Bloody Mary [online], 31. 5. 2006, original link: http://bloodymary. blog.cz/0605/tak-nejak-o-bm (This domain no longer exists; all links to Bloody Mary blog come from the archive of the article's author).

33 Editor's page. In Bloody Mary, 2003, No. 8, pp. 30-31.

34 KOLÁŘOVÁ, Jitka. Za genderovou rovnost subkultur!: Feminismus v podzemí. In A2 [online]. Praha, 2009, www.advojka.cz/archiv/2009/18/za-genderovou-rovnost-subkultur.

35 KOLÁ ŘOVÁ, Marta. Fairies and Fighters: Gendered Tactics of the Alter-Globalization Movement in Prague (2000) and Genoa (2001). In Feminist Review, 2009, Vol. 92, No. 1, p. 91, D0I: https//:doi.org/10.1057/ fr.2009.8

36 InterviewwithKamilaRemišováVěšínová,theauthorofBloodyMaryzine.Praha,11.5.2020.InKOPECKÁ2020, Př́loha (Appendix) 2, https://dspace.cuni.cz/bitstream/handle/20.500.11956/121600/120371484. pdf? sequence $=1 \&$ isAllowed $=y$.

37 Recirkus. S Evou o jejím workshopu In Bloody Mary, 2010, No. 15, p. 29.

38 EMČA. Hmm, takže móda ř́́káte... Odpor... Kontrakultura... Opravdu? In Bloody Mary, 2006, No. 11 , p. 11.

39 REVOLUCE EMČA. Politika v ére zábavy. In Bloody Mary, 2009, No. 14, pp. 4-6. 
Another characteristic was playing with a variety of formats that typically appear in women's magazines, such as psychological quizzes or advice for girls. They reprinted sexist texts from websites and mass media and showed their absurdity through humor and the ridiculing of gender stereotypes.

\section{Methodology of the Bloody Mary case study: Zines and the blogging platform}

This article summarises the case study of Bloody Mary and its changes between 2000 and 2010 in connection with the use of the Internet. The aim of the study was to monitor the changes of the zine after the expansion of Web 2.0 and to formulate how the use of the Internet could have influenced the process of the creation of Bloody Mary, its form, content, and creation process, as well as other activities of the collective.

The main source of information was the 15 issues of Bloody Mary, which I divided into three periods according to their relationship to computers and the Internet. It was crucial to examine the texts together with the format of the publication and to analyse the visual dimension as well. Data collected from zines were complemented by in-depth interviews ${ }^{40}$ with the creators Jitka Kolářová and Kamila Remišová Věšínová, as well as zine readers Tonča who published the zine Houpačka (The Swing) and Markéta Štěpánová, who published the magazine Př́má cesta (The Straight Path). ${ }^{41}$ Another source of information was the Bloody Mary blog. ${ }^{42}$

Through the analysis of these sources, several categories emerged. These categories changed during the existence of this publication and can be divided into three groups - 1) the content, 2) the form, and 3) the editorial practices and readers' reflections. The case study maps changes of the alternative medium after the collective began using graphics software, the Internet and the blog format. It was assumed that the Internet would affect the content and the visual appearance that the content would be more diverse, the authors would use many different and foreign sources, and the visual appearance would change. The Internet was also expected to have an effect on the organization of the zine's creation and the communication of the collective with other creators.

\section{Transformations of Bloody Mary and the Internet}

The subcategories described below map how Bloody Mary changed over time. These subcategories were grouped into three main categories. The issues were divided into three periods according to their relationship to the Internet. The first period (1st - 4th issue) consisted of issues created by copying, printing, and

40 The transcripts and recordings of the interviews are stored in the archive of the article's author.

41 Př́má cesta (The Straight Path) was an anarcho-feminist zine published by The Anarchofeminist group. For more details, see: http://followers.thcnet.cz/CyberNet/Punk-Rock\%20Rebels\%20Library/2.\%20 Anarchist\%20Newspapers/Anarxofeminizmus/anarchofeminismus.org/default.htm.

42 At the time of the research, the blog was still available online. Since August 2020, the blogging platform no longer exists. 
the cut-and-paste technique. The second period (5th -10th issue) consisted of issues created using the Internet. The third period (11th -15th issue) consisted of issues published after the Bloody Mary blogging platform was founded.

\section{Content}

\section{Thematic diversity}

In the first period, the zine described general topics the authors experienced every day - the subcultural scene and the experience with sexism in the anarchist movement and society. The Internet was not a main source of information - the creators often used literature from the Gender

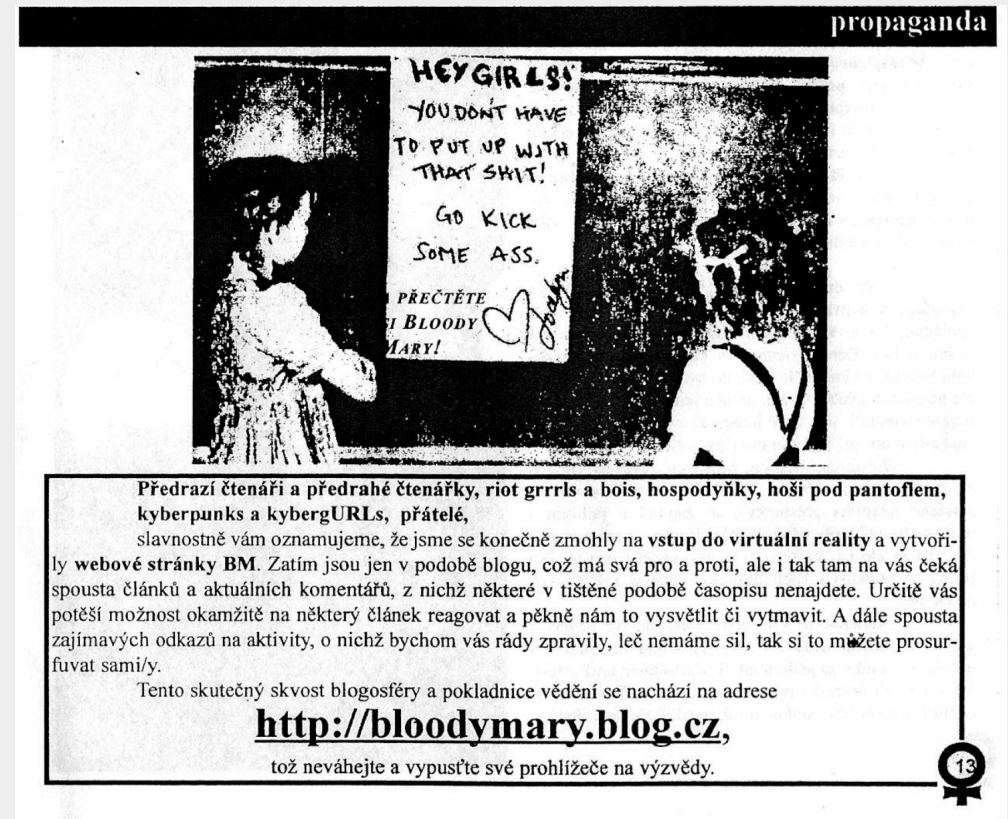

Figure 2. Source: Bloody Mary, 2006, No. 11, p. 13. Studies Library. ${ }^{43}$ In the second period, the creators focused on specific current events, and the diversity and number of topics grew. The influence of the Internet is represented in the greater thematic diversity, in the number of sources of information, and in the frequency of references to web sources. The author Kamila Remišová Věšínová said: "It was possible to gain access to more information and we got to know various Riot Grrrl websites around the world. [...] Sometimes we translated something directly from those pages." ${ }^{\prime 44}$ The influence of the Internet is milder in the third period. The main change is the emergence of controversial topics that would not have appeared in the Czech mainstream media - such as pornography, prostitution, or queer and transgender issues. The Internet was a great influence in finding new topics that the authors would not have learned about from the common Czech context. "We always discovered a topic, something that was not there before. I found it important to do this, to bring new ideas to this environment. [...] That would not be possible without the Internet. I had most of my resources from the Internet," said one of the authors, Jitka Kolářová. ${ }^{45}$

43 KOPECKÁ 2020, p. 72.

44 Interview with Kamila Remišová Věšínová, the author of Bloody Mary zine. Praha 11. 5. 2020. In KOPECKÁ 2020, Př́loha (Appendix) 2, https://dspace.cuni.cz/bitstream/handle/20.500.11956/121600 /120371484.pdf?sequence=1\&isAllowed=y.

45 KOPECKÁ 2020, pp. 52-53. 


\section{Feminism}

The zine creators admit that the development of their feminist thinking was stimulated by influences other than the Internet (age, environment, university). In the first period, the authors wrote about their first-hand experience; the concept of feminism was based on their personal experience of inequality, and the zine focused on basic feminist topics, gender stereotypes, and sexism. According to Jitka Kolářová: "A personal reflection of sexism, sexual harassment on the street and that I feel sick of it. [...] From the beginning, there were more aggressive texts, the need to vent anger." 46 In the second period the Internet served as a source of new theoretical information; the author Kamila Remišová Věšínová said that

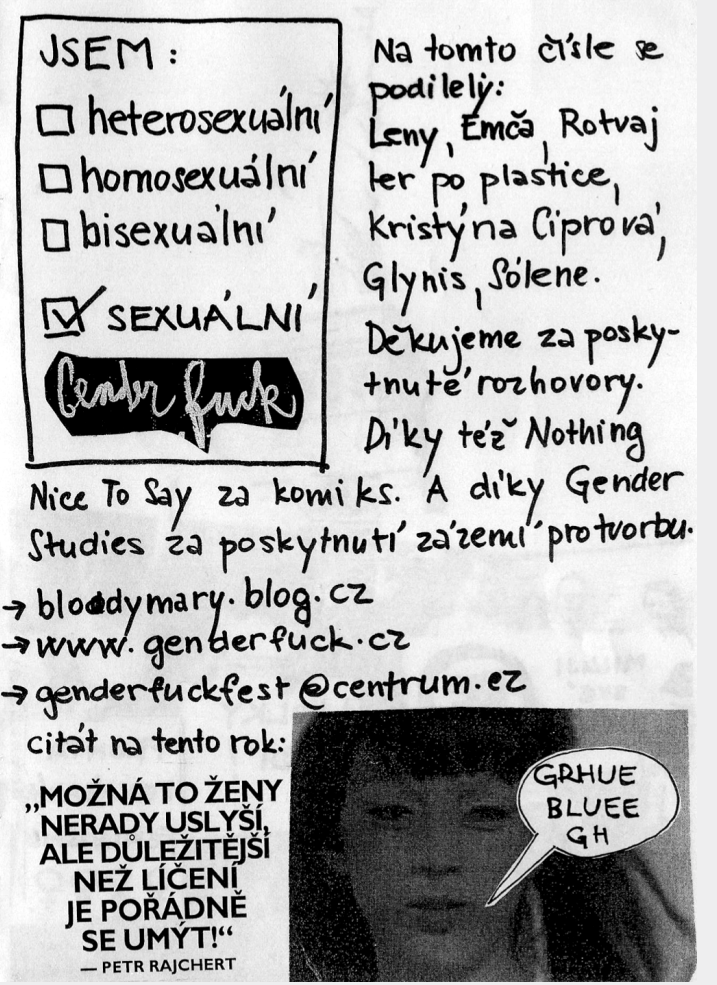

Figure 3. Source: Bloody Mary, 2010, No. 15, p. 46. the concept of feminism shifted from everyday problems to more serious issues: "As our knowledge deepened and we became more involved in various topics, the view on various problems and our awareness of them certainly changed." 47 The zine started to reflect other factors affecting the position of women in society (age, ethnicity, sexual orientation, class background), and the authors perceived feminism as a more complex, multi-layered movement. The third period was characterized by the inclusion of queer and LGBTQ+ topics that did not appear in the mainstream media. The zine included transgender issues, as the editorial staff wrote in one of their texts: "We are not women and men; we are humans. And that is why we don't care about gender!"48 Bloody Mary tried to bring these topics to the Czech context, where they had barely emerged before, according to the readers. However, the influence of the Internet is not absolute; the reflection of these topics was also impacted by the fact that the collective knew people who had their own queer experience. ${ }^{49}$

46 Interview with Jitka Kolářová, the author of Bloody Mary zine. Praha 29. 5. 2020. In KOPECKÁ 2020, Př́loha (Appendix) 1, https://dspace.cuni.cz/bitstream/handle/20.500.11956/121600/120371484. pdf? sequence $=1 \&$ isAllowed $=y$.

47 Interview with Kamila Remišová Věšínová, the author of Bloody Mary zine. Praha 11.5. 2020. In KOPECKÁ 2020, Př́loha (Appendix) 2, https://dspace.cuni.cz/bitstream/handle/20.500.11956/121600/120371484.pdf?sequence=1\&isAllowed=y.

48 Gender Fuck Fest. In Bloody Mary, 2009, No. 14, p. 54.

49 KOPECKÁ 2020, p. 58. 


\section{Subculture and the anarchist movement}

In the first period, the authors wrote about their own immediate experience with sexism in the punk scene - the absurdity of fighting for the poor, the weak, and the unequal and then laughing at feminists. ${ }^{50}$ The main change in the second period was the growing number of interviews with women from many different subcultures. The Internet connected the authors with activist from abroad, as Jitka Kolářová described: "In the Riot Grrrl movement there was one big group, Riot Grrrls Europe, which had its own smaller groups that had their own sites. [...] It had become more common for people to use the Internet, even in the context of other feminist groups across Europe. ${ }^{\prime 51}$ In the third period, the Internet served as a source of theoretical information for longer articles reflecting the broader social context, for example the commodification of punk fashion: "This is why the fashion of fishnet tights and miniskirts could have been created." ${ }^{\prime 52}$ In connection with exploring LGBTQ+ issues, they also criticized the lack of queer themes in the anarchist scene: "Why is it not connected with LGBTQ+ activism at all? Why is there practically no queer community that would subscribe to the principles of DIY and autonomy?"53

\section{Activism}

The first period was characterized by describing basic left-wing issues, such as criticism of capitalism and globalization and their impact on the unequal position of women. A great example was the fourth issue, which focused completely on globalization. ${ }^{54}$ In the second period, the Internet influenced the critique of globalization, which became more specific; the authors used more complex terms to describe some of the social phenomena - such as neoliberalism and market economy: "The logic of neoliberal globalization is based on the economy of the market and production, not on the economy of the household, which is the centre of women's lives. ${ }^{\prime 55}$ The Internet served as a source of theoretical information as well as news about world events. The last period focused on the position of unprivileged people. However, the respondents mentioned that changes in this category could be impacted by the fact that some of them had started studying at university ${ }^{56}$ so the influence of the Internet was not very strong.

\section{Form: From an amateur zine to a magazine (and back)}

\section{The zine format}

Changes in the production technique influenced the form of the Bloody Mary zine. In the first period, it was an amateur, chaotic publication, created using scissors,

50 Proč Bloody Mary? In Bloody Mary, 2000, No. 1, p. 2.

51 Interview with Jitka Kolářová, the author of Bloody Mary zine. Praha 29. 5. 2020. In KOPECKÁ 2020, Př́loha (Appendix) 1, https://dspace.cuni.cz/bitstream/handle/20.500.11956/121600/120371484. pdf? sequence $=1$ \&isAllowed $=\mathrm{y}$.

52 REVOLUCE EMČA. Ach jo, sexy punk. In Bloody Mary, 2006, No. 11, p. 6.

53 REVOLUCE EMČA. Ladyfest Leipzig Report. In Bloody Mary, 2008, No. 13, p. 49.

54 Úvodem... In Bloody Mary, 2000, No. 4, p. 1.

55 WICHTERICH, Christa. Globalizovaná žena. Zprávy o budoucí nerovnosti. In Bloody Mary, 2001, No. 5, p. 31.

56 KOPECKÁ 2020, p. 91. 
glue, and a copy machine. The articles contained themes mostly from the personal sphere of the authors. The creators experimented with the format and genres and tried different ways of expressing their opinions. They did not include the sources of their information, and it was typical to present broader structural problems through specific experiences. The texts on the pages were sometimes lacking headlines, and the authors didn't pay attention to the regularity of the section markings. "I didn't come to the zine until about the fifth issue. The girls used to copy it in kind of a 'punk' way; they used glue and a collage [...]. They didn't use the Internet much at the beginning" ${ }^{57}$ said Jitka Kolárová.

In the second period, the zine was prepared on a computer by Kolářová. The creators used the Internet as a source of information and inspiration. These changes were strongly reflected in the format - the zine looked more like a magazine now. Personal, intimate, and funny texts were on the decline and longer, theoretical in-depth articles appeared. The collective started using a large number of web sources. The format of the zine was clean and regular. The author Kamila Remišová Věšínová said that thanks to the Internet, it was easier to gain access to different sources of information: "We visited various Riot Grrrl sites. [...] Sometimes we translated something directly from those pages. Because we were decent college students, we all wrote the sources carefully[...] But definitely not everything was from the Internet."58

After creating the blog, the collective returned to the original zine format. The number of personal articles increased, and the format was looser, funnier and more experimental: "It was already 'retro', because the possibilities (to make the zine on a computer) were there, but we decided that it would probably be better to do it the 'old way." paper medium and the blog had different roles - the zine was funny and personal, while the blog was informational. The authors returned to the original format of the zine, because the preparation on the computer was too difficult for one person, and some members of the collective were dissatisfied with the result. They also perceived this method as a hierarchization of the editorial process. ${ }^{60}$

\section{Visual dimension}

In the beginning, Bloody Mary was a punk amateur zine, unedited and created with glue and copy machines. ${ }^{61}$ Direct evidence of the creative process can be found in the first issues - the title page is not completely copied and therefore the visual

57 Interview with Jitka Kolářová, the author of Bloody Mary zine. Praha 29. 5. 2020. In KOPECKÁ 2020, Př́loha (Appendix) 1, https://dspace.cuni.cz/bitstream/handle/20.500.11956/121600/120371484. pdf? sequence $=1$ \&isAllowed $=\mathrm{y}$.

58 Interview with Kamila Remišová Věšínová, the author of Bloody Mary zine. Praha 11.5. 2020. In KOPECKÁ 2020, Př́loha (Appendix) 2, https://dspace.cuni.cz/bitstream/handle/20.500.11956/121600/120371484.pdf?sequence=1\&isAllowed=y.

59 Interview with Jitka Kolářová, the author of Bloody Mary zine. Praha 29. 5. 2020. In KOPECKÁ 2020, Př́loha (Appendix) 1, https://dspace.cuni.cz/bitstream/handle/20.500.11956/121600/120371484. pdf? sequence $=1 \&$ is Allowed $=y$.

60 KOPECKÁ 2020, p. 120.

61 KOPECKÁ 2020, p. 75. 


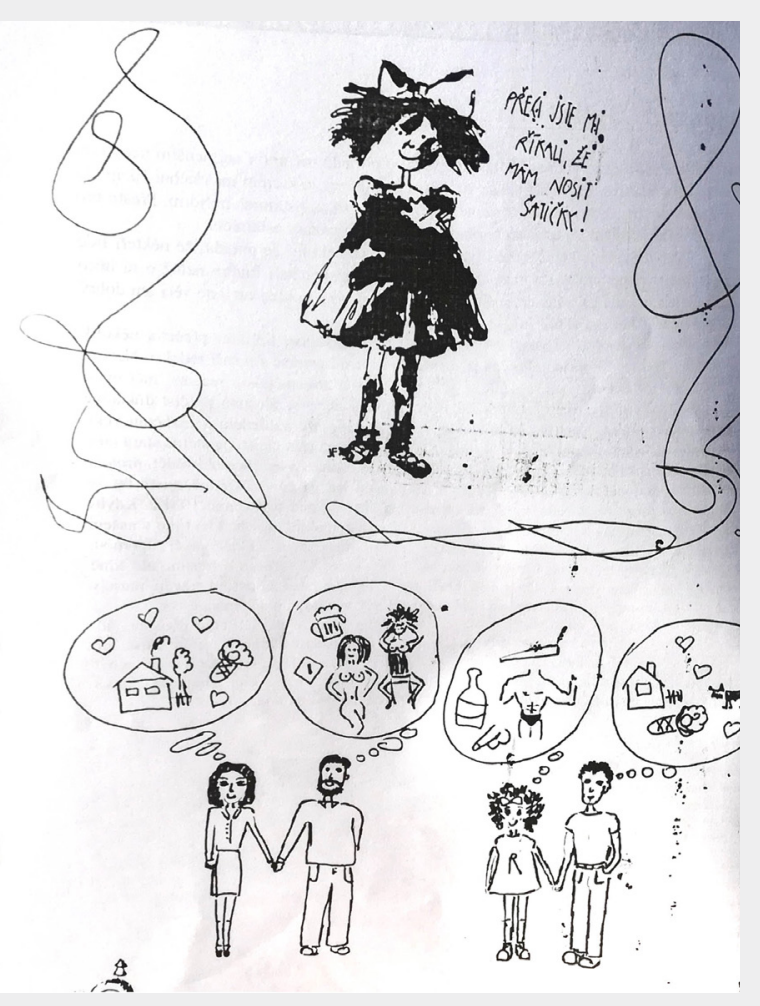

Figure 4. Source: Bloody Mary, 2000, No. 2, p. 23.

In the third period, the authors stopped using the graphics program and returned to the original method of creating the zine. They used many visual elements scattered on the pages and experimented with photographs, illustrations and drawn elements. The pictures were often modified, especially pop culture symbols. Disney princesses had chains drawn over them; ${ }^{63}$ the Statue of Liberty wore a veil and held a grenade in her hand. ${ }^{64}$ The printed texts were cut out and glued to various backgrounds and completed with handwritten inscriptions: "One weekend, we created this thing that lies in front of you - the result of working with paper, glue, scissors, and remnants of creativity. Leny fought with

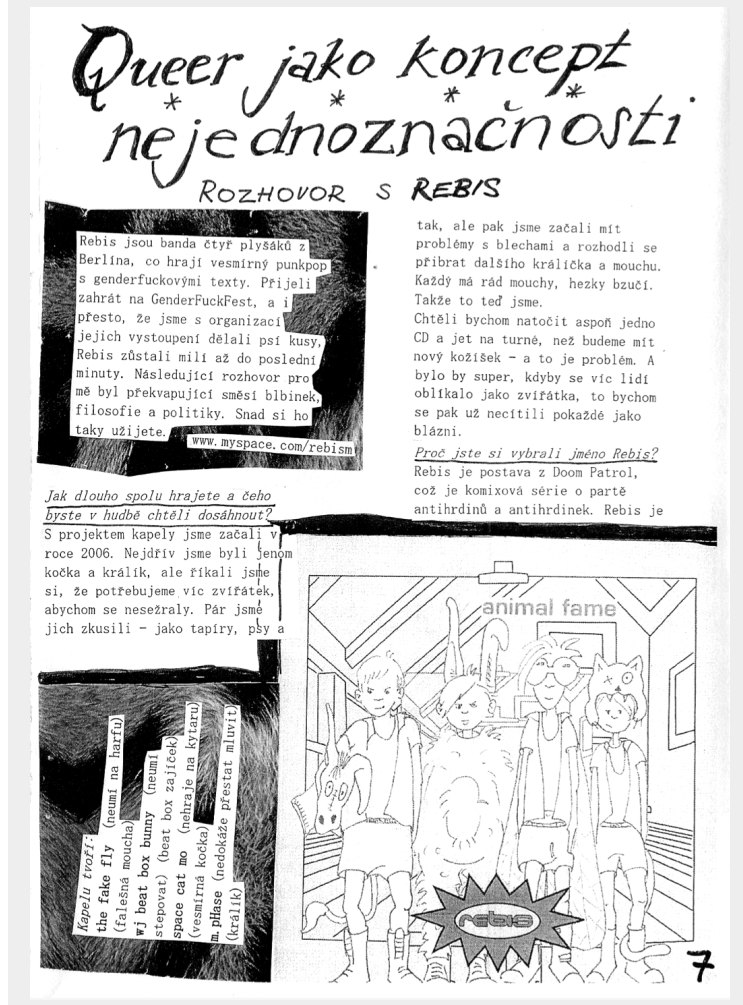

Figure 5. Source: Bloody Mary, 2010, No. 15, p. 7.

62 Editor's page. In Bloody Mary, 2003, No. 8, p. 51.

63 Bezprecedent LTM, radikální queer akce. In Bloody Mary, 2010, No. 15, p. 36.

64 Zamyšlení jedné queer. In Bloody Mary, 2010, No. 15, p. 2. 
the matter by millimeters, while Emča sometimes got lost in the dark corners of glued graphics. [...] But it was fun!"65

\section{Editorial practice and readers' reception}

\section{Editorial practice}

The year 2001 was crucial for the editorial practice; two new members joined, one of whom remained - Jitka Kolářová. ${ }^{66}$ Until the fifth issue, the zine was created using a copier and the cut-and-paste method. Kolárová initiated the preparation of the further issues on the computer using the graphics program Quark. The introduction of the computer graphics program was influenced by the activist movement in 2001: "We met many people during the activist meetings, and they described the benefits of using a computer." 67 The zine looked more professional when it was professionally printed by a printing house: "The print could be paid with the money earned earlier. It looked better."68 According to the reader and editor of zine Př́má cesta (The Straight Path) Markéta Štěpánová, with the arrival of Kolárová, the publication changed for the better: "There was more content than before. Before that, it was just about the form of the zine for me, and I didn't enjoy the form that much. By the time the content and the thematic articles appeared, I started to buy it." 69

The final form was created by Kolářová when she gathered most of the materials from the rest of the collective; it was up to her what the zine would look like: "I spent the morning by the Xerox machine and the afternoon at home among stacks of paper. My room turned into a small manufactory. [...] My room is covered with white and red papers in several layers, broken staples and pyramids of folded Bloody Mary. My hands are cut a little bit from the staples and edges of the paper, my knees are hurting from few hours sitting on the floor."70

Later, both techniques were combined: first, the materials were printed and then arranged and copied. In the last two issues, the collective returned to the original method of cutting, gluing and copying the pages of the zine: "The graphics was very difficult to make for me. [...] Sometimes people were dissatisfied with the appearance of their article or I received an article without a title. Such moments were annoying for both sides, so we decided to make it with the original method again.” Jitka Kolářová remembers that one of the authors also thought Kolářová's

65 EMČA - LENY. Editor's page. In Bloody Mary, 2010, No. 15, p. 1.

66 EMČA REVOLUCE. Tak nějak o BM. In Bloody Mary [online], 31. 5. 2006, original link: http://bloodymary. blog.cz/0605/tak-nejak-o-bm (This domain no longer exists).

67 Interview with Jitka Kolářová, the author of Bloody Mary zine. Praha, 29. 5. 2020. In KOPECKÁ 2020, Př́loha (Appendix) 1, https://dspace.cuni.cz/bitstream/handle/20.500.11956/121600/120371484. pdf? sequence=1\&isAllowed $=y$.

68 Interview with Kamila Remišová Věšínová, the author of Bloody Mary zine. Praha, 11.5. 2020. In KOPECKÁ 2020, Př́loha (Appendix) 2, https://dspace.cuni.cz/bitstream/handle/20.500.11956/121600/120371484.pdf?sequence=1\&isAllowed=y.

69 Interview with Markéta Stěpánová, the reader of Bloody Mary zine and the author of anarcho-feminist zine Př́má cesta (The Straight Path). Praha, 25. 6. 2020. In KOPECKÁ 2020, Př́loha (Appendix) 3, https://dspace.cuni.cz/bitstream/handle/20.500.11956/121600/120371484.pdf?sequence=1\&isAllowed=y.

70 REVOLUCE EMČA. Emča v kopírce - takže BM\#1-4 jsou na světě! In: Bloody Mary [online], 6. 3. 2008, original link: http://bloodymary.blog.cz/0803/emca-v-kopirce-takze-bm-1-4-jsou-na-svete (This domain no longer exists). 
role in designing the zine resulted in a certain hierarchy: "Leny said it bothered her, because it was a kind of power. It was quite non-consensual."71 It was possible to make Bloody Mary as a print magazine, but the authors, including Jitka Kolářová and Kamila Remišová Věšínová, decided to create it in the DIY ethos. They made the last two issues together - Jitka Kolářová described it as a positive experience: "The collective creation was great; the whole group decided on the layout of the zine, the pictures and everything else."72

\section{Readers' reception and the authors' perception of the audience}

Over the time, the zine's number of copies reached one thousand $;^{73}$ however its circulation fluctuated as the readers asked the authors to send them copies of volumes from the previous years. ${ }^{74}$ The zine's relationship with readers is an important element of Bloody Mary as a type of participatory medium. This element changed over time, although not as much as other categories. At the beginning, readers were perceived as critics of feminism, who do not know much about it. In the second period, the collective tried to involve the audience in the content of the zine-through interviews and polls. The collective communicated with readers through their newly established e-mail account. In the third period, the authors wanted to publish readers' texts on their new blog, because they did not have the capacity to involve them all in the zine, ${ }^{75}$ and this is one of the main impacts of the Internet on the last five issues.

The readers of Bloody Mary were mainly from the anarchist movement - both women and men. The author Jitka Kolářová said that due to her experience, the readers' perception of the zine was mostly positive: "One of my friends told me, that when she was fifteen, she used to read Bloody Mary. She lived in a village and this zine was very helpful to her - many things bothered her at that time and the zine was important to her." Due to Kolářová, many readers appreciated that their zine was partly humorous and the feminist subjects were not approached in an overly serious manner. ${ }^{76}$ Some of the readers also welcomed that women in the anarchist movement were more active. "I am glad there is finally a feminist-punk magazine, and I hope that it won't be the only one existing. [...] There are millions of music zines, so this is a welcome change for me," one of the male readers wrote to the zine's authors. ${ }^{77}$

71 Interview with Jitka Kolářová, the author of Bloody Mary zine. Praha, 29. 5. 2020. In KOPECKÁ 2020, Př́loha (Appendix) 1, https://dspace.cuni.cz/bitstream/handle/20.500.11956/121600/120371484. pdf?sequence=1\&isAllowed =y.

72 Interview with Jitka Kolářová, the author of Bloody Mary zine. Praha, 29. 5. 2020. In KOPECKÁ 2020, Př́loha (Appendix) 1, https://dspace.cuni.cz/bitstream/handle/20.500.11956/121600/120371484. pdf?sequence $=1 \&$ isAllowed $=\mathrm{y}$.

73 PARUS, Ondřej. Lepidla a frustrace zbylo dost: Knižní pocta českým fanzinům. In A2 [online]. Praha, 14. 3. 2018, https://www.advojka.cz/archiv/2018/6/lepidla-a-frustrace-zbylo-dost

74 REVOLUCE EMČA. Starší čísla BM k mání. In: Bloody Mary [online], 18. 1. 2008, original link: http:// bloodymary.blog.cz/0801/starsi-cisla-bm-k-mani (This domain no longer exists).

75 EMČA. Editorial's page. In Bloody Mary, 2008, No. 13, p. 67.

76 Interview with Jitka Kolářová, the author of Bloody Mary zine. Praha, 29. 5. 2020. In KOPECKÁ 2020, Př́loha (Appendix) 1, https://dspace.cuni.cz/bitstream/handle/20.500.11956/121600/120371484. pdf?sequence $=1 \&$ is 1 llowed $=y$.

77 Letters from readers. In Bloody Mary, 2000, No. 4, p. 49. 
However, the readers perceived the format of the zine very differently and some of them did not like the zine's approach to feminism. One of them, Markéta Štěpánová, was very critical: "I didn't like the punk image of the zine. It seemed unnecessary to copy it and glue it all together at a time when it was possible to prepare it in a graphics program." Štěpánová thought the alternative magazines should be tidy and clean in order to reach the widest possible audience. At the same time, however, she perceived Bloody Mary as a positive part of the activist scene: "The benefits of Bloody Mary are indisputable. Even though I didn't like the zine format at the time that it was torn and glued, now it seems great to me."178

In contrast, reader Tonča liked the punk audacity of the zine: "I especially liked that it was so cheeky. When I compare it to Př́má cesta [...], the audacity and openness of Bloody Mary's style was such a reflection of me at the time. What the anarchofeminists from Prague criticized, paradoxically, I liked - it was easier to read." Tonča thinks that the Bloody Mary collective was a bit spontaneous rather than thinking deeply about the zine's topics, but due to her opinion, this is exactly what is sometimes needed for a zine to be more accessible for people. On the other hand, Tonča was critical of the way the zine became modified with the introduction of graphics software to the process of its creation: "I like classic paper zines; otherwise I think it is useless; it costs money (to print the zine in the printing house). The content was important to me." She also appreciated the playfulness of the zine format: "When it is just about the text, I don't like it so much."79

\section{Conclusion}

It is important to highlight that some categories evolved under several different influences - the Internet and the environment in which the collective operated influenced the development of their approach to feminism and queer issues. The influence of the Internet was strongest in the transformation of the zine's format and in the number of web sources of information used by the authors. Bloody Mary changed from an amateur, punk, personal publication into a medium reminiscent of a magazine. The visual dimension evolved similarly: the punk crooked visual changed into modified, clean publication prepared on a computer and printed in a printing house. Because of a hierarchy that emerged from the process, when only one person was preparing the final form of the zine, the collective returned to the original approach.

The content of the zine also changed; the number of web resources grew, and in-depth theoretical articles replaced the intimate, personal texts. A more theoretical approach caused a change in the perception of the feminist issues in a broader social context. The Internet allowed the authors to connect with the foreign subcultural and activist scene and to communicate with readers. Bloody

78 Interview with Markéta Štěpánová, the reader of Bloody Mary zine and the author of anarcho-feminist zine Př́má cesta. Praha, 25. 6. 2020. In KOPECKÁ 2020, Př́loha (Appendix) 3, https://dspace.cuni.cz/ bitstream/handle/20.500.11956/121600/120371484.pdf? sequence=1\&isAllowed $=\mathrm{y}$.

79 Interview with Tonča, one of the readers of Bloody Mary zine and the author of zine Houpačka. Praha, 8. 7. 2020. In KOPECKÁ 2020, Př́loha (Appendix) 4, https://dspace.cuni.cz/bitstream/handle/20.500.11956/121600/120371484.pdf?sequence=1\&isAllowed $=y$. 
Mary brought many important topics into the Czech activist context - the zine drew attention to sexism and the unequal position of women in the movement and highlighted queer and LGBTQ+ issues and topics, which had not appeared in the Czech context before.

If we look at the development of Bloody Mary in the context of digital communication and the Internet, we see that both media exist in a symbiosis and complement each other. The Internet serves as a tool for creating an alternative medium; the creators used it in a specific way in terms of translating foreign texts and "stealing" images. Thanks to the Internet, the zine's content is more diverse. After the creation of the blogging platform, the function of the publication changed - at the beginning, Bloody Mary informed about current events, but as the interval of publishing the issues increased, the informational function was no longer relevant. At this moment, the Bloody Mary blog took over this function and informed readers with the most up-to-date information about the Prague activist scene. It was a space for the contributions of the audience and virtual discussions between the creators and the readers in the comments section. Funny formats and personal, intimate texts that were not suitable for the blog were added to the zine. There was a certain division of roles between these two different but complementary media. As Jitka Kolářová said, the physical dimension of the zine was important to the authors: "There was this certain feeling of it: 'Look, I made this!' A piece of something you can take with you. It occurs to me that in a sense it can support relationships. [...] The fact that you exchange a zine with someone or write to them, even if you write them an e-mail, it still somehow fosters relationships." ${ }^{80}$ Although the collective founded the blog, they still wanted to publish the material zine and never completely switched to the digital format.

The return to the collective creation of the zine was an important moment, caused by the fact that one of the members felt that Kolářová, who prepared the entire zine, had disproportionate power, and therefore, a certain kind of hierarchy emerged in the process of making the zine. The medium, which by its nature was supposed to be democratic, became partly hierarchical due to the new technology. Lévy describes the optimistic concept of "collective intelligence", where the Internet helps to establish a collective creative cooperation in an environment of heterogeneous sources of information. It is a dimension of power sharing and prosperity guaranteed by a vast amount of information - and this should lead to a certain cyber-democracy, where everyone can participate. ${ }^{81}$ Despite these optimistic assumptions, the Bloody Mary collective achieved the opposite result after using computers - a greater hierarchizing. Consequently, the authors returned to the collective zine-making.

80 Interview with Jitka Kolářová, the author of Bloody Mary zine. Praha, 29. 5. 2020. In KOPECKÁ 2020, Př́loha (Appendix) 1, https://dspace.cuni.cz/bitstream/handle/20.500.11956/121600/120371484. pdf?sequence=1\&isAllowed $=y$.

81 LÉVY, Pierre. Collective Intelligence, A Civilisation: Towards a Method of Positive Interpretation. In International Journal of Politics, Culture, 2005, Vol. 18, No. 3/4, pp. 191-193, DOI: 10.1007/s10767-0069003-z. 
The case study summarized in this article describes the effects of the Internet on alternative media publishing. Zines survived the digital era because the technology used during zine production brought a hierarchy into the process of zine-making, which was initially based on democratic, DIY principles. In contrast, a key factor in this increased hierarchizing was centered on some of the authors not having access to computers or the skills in using graphics programs. As such, collective zine-making persisted, since it was perceived as a democratic process where everyone could participate, and the Bloody Mary team emphasized the fact that making the zine together was a fun, pleasant process filled with friendship and freedom of expression. In this sense, these elements could not be substituted by digital communication at the time, since not many people owned a computer with an Internet connection. The zine served as a unique medium, informing about both events of the Czech activist scene and themes not included in the Czech mainstream media, such as LGBTQ+ issues. Finally, after returning to the original cut-and-paste form, Bloody Mary ceased to exist after two more issues, as the creators started working full-time and had their own families. The question is what a similar process would look like today, in an environment where we create cultural texts almost always in a virtual space and almost never with a printer, scissors, or glue.

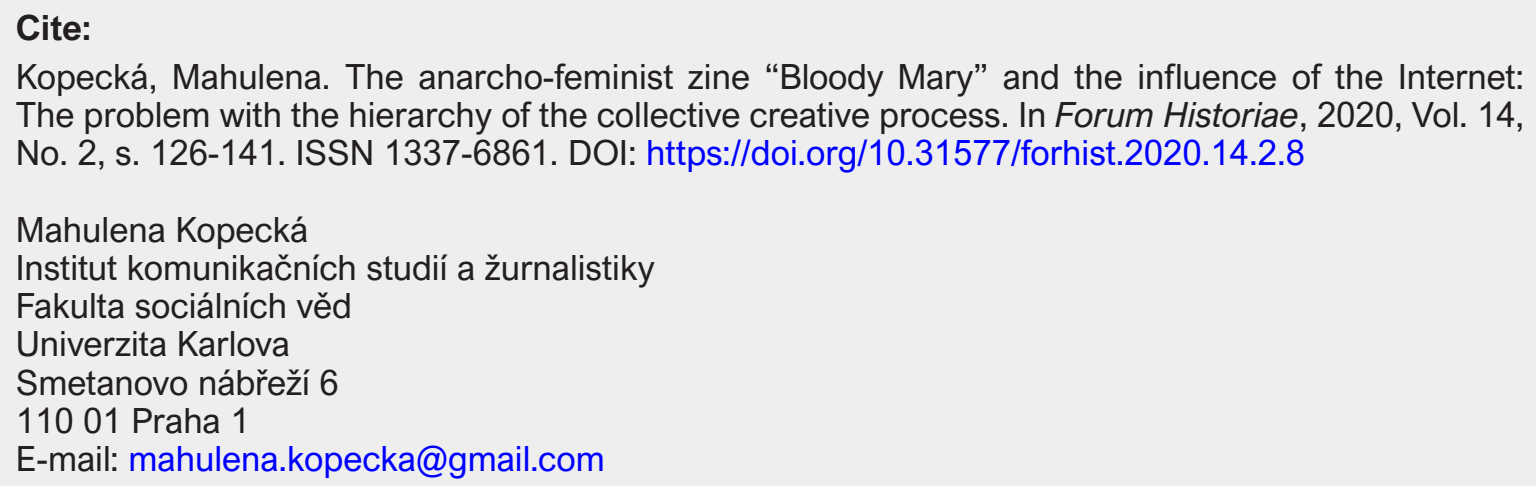

